\title{
Food Waste Behavior among Romanian Consumers: A Cluster Analysis
}

\author{
Cristina Bianca Pocol ${ }^{1, *} *$ (D) Margaux Pinoteau ${ }^{2}$, Antonio Amuza ${ }^{3}$, Adriana Burlea-Schiopoiu ${ }^{4}(\mathbb{b}$ \\ and Alexandra-Ioana Glogovețan ${ }^{1}$ \\ 1 Department of Animal Production and Food Safety, University of Agricultural Sciences and Veterinary \\ Medicine of Cluj Napoca, 400372 Cluj Napoca, Romania; alexandra.glogovetan@gmail.com \\ 2 Frate Formation Conseil, 90000 Belfort, France; margaux.pinoteau2@laposte.net \\ 3 Department of Sociology and Social Work, University of Bucharest, 030018 Bucharest, Romania; \\ amuza.antonio@gmail.com \\ 4 Department of Management, Marketing, Business Administration, University of Craiova, \\ 200585 Craiova, Romania; adriana.burlea@gmail.com \\ * Correspondence: cristina.pocol@usamvcluj.ro; Tel.: +40-740-176-785
}

Received: 29 October 2020; Accepted: 18 November 2020; Published: 20 November 2020

\begin{abstract}
The main objective of the current study was to conduct an investigation at the national level in order to identify types of consumers depending on their perception of food waste. To do this, an online survey was carried out on a sample of 2541 respondents. Using a K-means clustering model, three clusters of consumers were identified. Cluster 1, "Careless", consumers who dispose of food and food waste carelessly, are people who come from rural areas or small cities and have a rather low level of education. They do not have much information on the subject of food waste and do not seem to consider it "a problem". Cluster 2, "Precautious", composed of responsible people who do not throw away food, are well-informed and consider that all actors in the agri-food chain have a share in the food waste problem. Those who belong to cluster 3, "Ignorant", are mostly from urban areas and have a high level of education. They were not raised to prevent food waste and therefore lack such habits as adults. They have a fair awareness of this subject, but they do not consider themselves responsible for food waste. The results obtained indicate the need to continue the awareness and education campaigns initiated at governmental and civil society level.
\end{abstract}

Keywords: clusters; consumers; food waste; habits; education; Romania

\section{Introduction}

Food loss and waste (FLW) is a global issue [1] that has become an increasingly debated topic in recent years by governments, business representatives, non-governmental organizations, scientists, and also by the worldwide public [2,3]. There is a strong consensus around FLW at international level, due to its importance in terms of reducing production costs, improving food security and ensuring environmental sustainability [4]. There are various definitions of FLW in the scientific literature according to analysts and stakeholders' opinions and perceptions [4]. Food loss concerns all segments of the food supply chain, from production, storage, processing to distribution, excluding "the point where there is interaction with the final consumer" [4]. "Food waste is the result of purchasing decisions by consumers, or decisions by retailers and food service providers that affect consumer behaviour" [4]. According to a systematic review of the literature made by Van der Werf and Gilliland [5], there is a great variability in estimating FLW because of the different methodologies used in collecting data, directly or indirectly. 
Identifying solutions to the problem of FLW is a major challenge for the entire food supply chain $[1,6]$. Approximately one third of world food production is wasted each year [6,7], and socio-economic and environmental consequences being increasingly severe [8]. Even at the EU level, there is growing concern about the issue of FLW [9]. This concern is part of the Sustainable Development Goals [10] (SDGs) that have among their objectives the fight against climate change, the eradication of hunger, malnutrition and the achievement of savings by farmers, economic entities and individual households [9]. Given the importance of this topic, many international initiatives have been taking place to solve the FLW problem [11].

According to the Fusions [12] report, in the 28 Member states "around 88 million tonnes of food waste are generated annually with associated costs estimated at 143 billion euros.". Food waste is responsible for producing approximately $8 \%$ of greenhouse gas emissions globally [9]. However, at the level of the EU, the statistics from 2018 indicate a worrying figure which shows that "some 33 million people in the EU cannot afford a quality meal every second day" [9]. Based on a report made in 2019, within the Bioregio [13] project, the amount of food waste varies from approximately $186.06 \mathrm{~kg} / \mathrm{capita} /$ year in Spain, to $129 \mathrm{~kg} / \mathrm{capita} /$ year in Romania and only $29 \mathrm{~kg} / \mathrm{capita} /$ year in France [13].

The EU suggests an official methodology for quantifying food waste by the Member states, based on diaries and waste composition analysis. This is part of the "EU action plan for the circular economy" [14]. Despite the lack of use of this methodology, there are still some examples of national studies, which followed the EU recommendations. According to studies carried out in Finnish households, the amount of food waste generated each year is around $23 \mathrm{~kg}$ per capita and $63 \mathrm{~kg}$ per household, represented mostly by fresh and perishable food: vegetables, home-cooked food, and milk products [15,16]. A recent diary study carried out by German scientists shows that household food waste adds up to $89.5 \mathrm{~kg} /$ year and per capita food waste counts $44.6 \mathrm{~kg} / \mathrm{year}$. The most discarded food products are vegetables, fruits, and bread [17]. Giordano et al. [18] stressed the importance of using alternative methods to assess food waste at household level. Their results confirmed that the use of questionnaires is less accurate than the use of diaries: "the average food waste value is significantly higher when gathered through diaries, while questionnaires are able to catch less than one-third of food waste determinants" [18].

According to Eriksson et al. [19], there is an EU legislation directly or indirectly related to the subject of food waste. This legislation creates effects that contradict the interests of the stakeholders involved in reducing food waste process and generate a low desired impact. Therefore, much more in-depth research into the interaction of the consequences of the application of food waste legislation is necessary for a harmonious integration of public policies in this area [19]. Romanian legislation on food waste has its origins in the EU legislation [20] and is embodied in specific measures of education, communication, and information [21]. All the links of the agri-food chain (from agricultural production, management, storage, processing, and distribution to the final consumer) face the problem of FLW, for various reasons (e.g., improper management of food during the harvesting and storage process, incorrect labelling, and inadequate purchasing and consumption habits of final consumers) [1]. Thus, according to the Law no. 217/2016 [22] on reducing food waste, all economic operators in the agri-food sector should voluntarily get involved in campaigns conducted by the authorities and should initiate such actions on their own.

\section{Literature Review}

In Romania, there are few studies on the role and behavior of actors involved in the fight against food waste. Gheorghescu and Bălan [23] underline the importance of the inclusion of all stakeholders in the prevention and reduction of food waste and the need to educate citizens about the notion of food waste and its causes. In the Romanian context, they consider that a coherent strategy for reducing and preventing food waste is needed, and it should be accompanied by rural development policies leading to food security [23]. 
Another study conducted by Cantaragiu [24] analyzed the problem of food waste (in terms of social responsibility) at the level of a well-known retailer in Romania, highlighting the main aspects that should be considered for the success of a social entrepreneurship initiative (e.g., clear articulation of the problem and solutions, mobilization of the civil society actors, perseverance, and achieving a strategy in line with the resources held by the retailer). The study [24] concludes that food waste management based on the principles of social entrepreneurship can lead to a sustainable competitive advantage for traders.

Dumitru and Burghiu [25] identified models of logistics good practices regarding the process of donating food from economic entities (producers and traders) to people in difficulty, through NGOs. Their study recommends the need to support food banks by the local authorities, private companies and universities, in Romania. The development of the infrastructure and digitalisation in the fight against food waste is emphasized by researchers $[25,26]$ who believe that the role of computer applications is to connect potential sources of food waste with consumers in need of food.

Studies on the behaviour of Romanian consumers on the issue of food waste are, as in the case of other actors in the food chain, quite limited. However, there are some milestones in the scientific literature on the role of households and the final consumer in food waste management. Ghinea and Ghiuță [27] have investigated the behaviour, habits, and attitudes of young Romanians regarding food waste and identified the following reasons why they throw away food: expiration date (especially in the case of dairy products, meat, and eggs), too long period of storage of food in the refrigerator, inadequate storage methods, and deterioration of the appearance of food. They recommend carrying out awareness raising and education campaigns on label reading, shopping list planning and the use of food scraps [27]. Stefan et al. [28] demonstrated that the behavior oriented towards food waste among Romanian consumers is rather determined by the routine of planning and supplying food, the moral attitude, and control of being able to influence this routine. Thus, changing consumer attitudes, as well as awareness and education campaigns are factors that can have, in their opinion [28], a significant impact on reducing food waste. Following the research conducted on a sample of 900 respondents, from 153 cities in Romania, Iorga et al. [29] identified a representative individual profile for food waste: male consumer, under 35 years old, single, with a high level of education. The explanations found for the identified profile are the lack of interest in food resource management, deficit in time management, and the influence of modern consumerism-oriented marketing tools. According to the results obtained by Iorga et al. [29], there is a direct relationship between the income level and the amount of food waste: the higher the household income, the greater the amount of food waste.

The influence of the socio-demographic factors on the attitude of urban consumers towards the phenomenon of food waste in Romania was also studied by Cantaragiu [30] who demonstrated the existence of major differences between women and men, belonging to different age segments, regarding the attitude compared to food waste. Thus, women between the ages of 20 and 30 are more likely than men to feel guilty about throwing away food and to associate food waste with social inequality [30]. As they get older, women associate food waste more with financial irresponsibility [30].

A recent study conducted in Romania analyzed the behavior of consumers regarding food waste when they are on vacation, in tourist reception structures in rural areas [31]. The authors of this study showed that there is no significant impact of socio-demographic factors (gender and age) and the length of stay on the behavior of the Romanian tourists regarding food waste. On the other hand, Romanian tourists waste less food when consuming local specialties, organic food, and homemade products [31]. Food waste represents a serious problem not only for rural tourism, but also for all-inclusive segment of this industry. According to Okumus et al. [32], guests' cultural backgrounds highly influence the tourists' behaviours and the quantity of food waste generated.

The perception of the Romanian consumers regarding the understanding of the concept of food waste was evaluated by Caprita [33]. The results of the research indicating a large proportion, over $60 \%$ of respondents, of those who do not have information about food waste and who do not understand the information contained on the label, but who would be willing to learn. According to the participants in 
this study [33], the main people responsible for waste in the agri-food chain are households and traders (mainly retailers). The most wasted foods by Romanian consumers are cooked dishes, followed by fruits and vegetables [33]. Meat, a food very present in the Romanian diet, is much less wasted by consumers. The research conducted by Petrescu et al. [34] has demonstrated that only $13.3 \%$ of the meat consumed is perceived as wasted, a very small percentage compared to other foods. Chivu et al. [35] studied the impact of reductions on purchasing and consumption behavior in Romania, and implicitly on the quantities of food thrown away, showing that those who buy large quantities of food because they are on sale, without having a rational motivation or need, fail to always consume it and throw it away. The authors of the studies carried out so far in Romania have recommended additional research on the identification of consumer profiles, on food waste [29] and the influence of socio-demographic factors on food waste behavior [30]. Following the literature review conducted by us, no cluster analyses were identified, leading to the shaping of some segments of Romanian consumers regarding food waste. However, at the international level, there are studies that aimed to cluster consumers and a synthesis of them is presented below.

The exploration of consumers' attitudes towards food waste and their segmentation was carried out by Falasconi et al. [36], following a study conducted in two cities in Italy (Bologna and Viterbo). They identified several clusters of consumers, labelled as follows: "Unconcerned," "Selfish," "Responsible," "Indifferent," "Virtuous," "Careful," and "Aware" [36]. They also emphasized the need for targeted interventions on each cluster in order to raise awareness of food waste [36]. Another study conducted in Italy [37] aimed to understand the causes of food waste in households and clustered consumers according to their attitude towards food waste and their anti-waste behavior, outlining the following profiles: "The conscious-fussy," "The frugal consumer," "The exaggerating cook," "The conscious-forgetful type," "The unskilled cook," "The confused type," "The exaggerated shopper". Starting from the clusters obtained, the results of the study emphasize the importance of the monetary value of food waste [37]. Di Talia et al. [38] conducted an empirical analysis of the causes of food waste in a rural area, starting from the following assumptions: the extrinsic characteristics of the food, along with the frequency of shopping and the use of shopping lists are essential to reduce food waste. Profiling consumers in the following categories: "Non-aware consumers," "Consumers not aware but not wasteful," and "Conscious consumers" led to the suggestion of targeted actions for each identified profile [38]. A study conducted in the UK investigated whether household food waste is determined by a lifestyle food based on convenience food among young consumers [39]. The cluster analysis identified five consumer groups based on factors related to eating behavior: "Epicures" (refined food), "Traditional consumers," "Casual consumers," "Food detached consumers," and "Kitchen evaders" [39]. Daily food supply and consumption practices play a key role in combating food waste. Thus, Romani et al. [40] investigated how these practices (shopping and cooking) lead to food waste and how policy makers can implement effective strategies to influence them. Following a two-cluster analysis, Romani et al. [40] identified three consumer clusters that they named: "Virtuous," "Moderate," and "Waster." A similar analysis was carried out in Serbia [41], identifying two consumer profiles: "Uncaring food wasters" and "Caring." The main reasons why Serbian citizens throw away food are the expiration of food and the fact that it acquires unpleasant tastes and odors [41]. The collection of information on German consumer attitudes and perceptions of food waste led to the identification of three consumer profiles as following: "Guilty food wasters," "Unwitting food wasters," and "Careless food wasters". The authors of the study conducted in Germany considered that a simple consumer information campaign on food waste is insufficient; requiring the development of educational materials on how food scraps should be used and on reading and understanding the information provided by the label [42]. Understanding attitudes, the perceptions and behaviors of Swiss consumers regarding the issue of food waste and their clustering were the objectives of the study conducted by Delley and Brunner [43]. They identified six consumer segments, which differ significantly in attitudes and behaviors related to food consumption and food waste: "The conservative," "The self-indulgent," "The short-termist," "The indifferent," "The consumerist," and "Eco-responsible". According to Delley 
and Brunner [43], the results justify the need of the development of a strong and specific action plan dedicated to problematic segments, by all stakeholders involved (e.g., the state, retail companies, companies in the food industry, end consumers, NGOs, and cultural organizations).

In the framework of the literature review, we arrived at the conclusion that research carried out so far on food waste in Romanian households is limited. To the best of our knowledge, the existing studies are focused only on descriptive analyses regarding the anti-waste behavior of Romanian consumers.

Starting from the recommendations formulated in the conclusions of previous studies and from the lack of a segmentation of Romanian consumers regarding food waste, the authors of this research aimed to fill this gap by conducting a national study and identifying consumer clusters. The novelty of the research is the clustering approach that allows creating different segments of Romanian consumers based on their perceptions, attitudes and beliefs on food waste.

\section{Materials and Methods}

In order to study the attitude and beliefs of Romanian consumers regarding food waste, an online survey research method was used. With the aim of collecting as many answers as possible, but also due to the restrictions imposed by the health crisis caused by COVID 19, the distribution of the link related to the questionnaire was done by the snowball method. Additionally, to promote the study, it was published by NGOs on various public debate groups.

According to the literature review, there are various approaches regarding the methods used to quantify household food waste: questionnaires, diaries, waste sorting and composition analysis [44-46]. As it is already widely confirmed by scientists, questionnaires do not reflect real behaviors, but just intentions, attitudes, and beliefs which most of the time are different from the real quantities discarded [47]. Based on the results obtained by [47], there are few studies at EU level, which provide a quantitative estimation of household food waste.

The main purpose of the present study was to evaluate the Romanian consumers perceptions, attitudes and beliefs on food waste. Thus, despite the limitation of the questionnaire instrument, the authors considered this to be a suitable approach in the first stage of the evaluation of household food waste in Romania. The second stage of the research will be represented by a quantitative estimation of household food waste by using diaries and waste composition analysis.

\subsection{Questionnaire Development}

The questionnaire has six sections containing 42 items as following: the Section 1 contains a series of socio-demographic questions, and the Section 2 assessed the respondents' childhood habits. The inclusion in the questionnaire of the questions related to childhood habits was based on the results obtained by Le Borgne [48] who validated through his research the hypothesis that childhood concerns and parents' education regarding food positively influence the importance given to the subject of food waste, in adulthood. Sections 3 and 4 include questions about the buying habits and cooking habits of the respondents, which represented the attitudes and behaviors associated with the purchase and consumption of food. Section 5 was the focus of the questionnaire and referred to food waste habits. Section 6 covered a series of questions regarding respondents' changes in eating behaviors following the health crisis caused by the COVID-19 pandemic. The questionnaire included both dichotomous and multi-choice questions, as well as questions in which respondents were offered Likert-type scales (from "always" to "never," from "very important" to "not at all important," from "total agreement" to "total disagreement") to capture their position in relation to the research questions. The items that generated significant correlations in the statistical analysis are presented in Table 1. 
Table 1. Questionnaire items used in the analysis.

\begin{tabular}{|c|c|c|}
\hline Section Name & No. & Questions Description \\
\hline \multirow{5}{*}{$\begin{array}{c}\text { Socio- } \\
\text { Demographic Variables }\end{array}$} & Q1 & What is your gender? \\
\hline & Q2 & Indicate your level of education. \\
\hline & Q3 & What socio-professional category do you fall into? \\
\hline & $\mathrm{Q} 4$ & Where do you have your permanent residence? \\
\hline & Q5 & How many people make up your family? \\
\hline \multirow{9}{*}{ Childhood Habits } & Q6 & During your childhood, did you have the opportunity to spend your holidays in a village? \\
\hline & Q7 & During your childhood, did you have the opportunity to get involved in agricultural activities? \\
\hline & $\mathrm{Q} 8$ & During your childhood, did you have the opportunity to help your parents/grandparents cook? \\
\hline & Q9 & During your childhood, did you have the opportunity to help your parents/grandparents buy food? \\
\hline & Q10 & During your childhood, did you have the opportunity to help your parents/grandparents clean the house? \\
\hline & Q11 & During your childhood, did your parents ask you to always finish eating what you have on your plate? \\
\hline & Q12 & During your childhood, did your parents ask you to have meals with your family? \\
\hline & Q13 & Did your parents ask you not to play with food during your childhood? \\
\hline & Q14 & During your childhood, did your parents ask you not to throw away leftover food and eat it later (the next day)? \\
\hline \multirow{10}{*}{ Food Waste Habits } & Q15 & Do you happen to throw away food? \\
\hline & Q16 & I freeze leftovers that I think I will not eat very soon. \\
\hline & Q17 & I arrange the food in the fridge by categories and depending on the temperature. \\
\hline & Q18 & I clean my fridge at least once a week. \\
\hline & Q19 & I check the expiration date before buying a food. \\
\hline & Q20 & I check the expiration date of food stored in the house/refrigerator. \\
\hline & Q21 & I try to estimate what a portion of food means when I buy/cook/order food. \\
\hline & Q22 & I pay attention to the way I store my food (where and how). \\
\hline & Q23 & I try foods I have not eaten before. \\
\hline & Q24 & I recycle the oil used for frying. \\
\hline \multirow{12}{*}{$\begin{array}{l}\text { General Information on } \\
\text { Food Waste }\end{array}$} & Q25 & How interested are you in avoiding food waste? \\
\hline & Q26 & Have you tried to adopt habits that help avoid food waste? \\
\hline & Q27 & When shopping, do you prefer to buy products in bulk or individually packaged? \\
\hline & Q28 & From the vegetables and fruits you buy, do you choose the ones that look better? \\
\hline & Q29 & Who do you think is responsible for food waste? [Farmers] \\
\hline & Q30 & Who do you think is responsible for food waste? [Agri-food industry] \\
\hline & Q31 & Who do you think is responsible for food waste? [Hypermarkets] \\
\hline & Q32 & Who do you think is responsible for food waste? [Small traders] \\
\hline & Q33 & Who do you think is responsible for food waste? [Customers] \\
\hline & Q34 & Who do you think is responsible for food waste? [Restaurants] \\
\hline & Q35 & Who do you think is responsible for food waste? [School canteens] \\
\hline & Q36 & Who do you think is responsible for food waste? [Government institutions] \\
\hline
\end{tabular}

\subsection{Data Collection}

The study was coordinated by researchers of the University of Agricultural Sciences and Veterinary Medicine, Cluj-Napoca, Romania. The questionnaire was pre-tested on a small sample of respondents, to improve the quality of data collection. The promotion of the questionnaire was done online, with the support of the the Francophone University Agency in Central and Eastern Europe (AUF ECO), the Food Waste Combat project team, actively involved in the fight against food waste in Romania, but also media representatives. The questionnaire was implemented online, between June and September 2020, the respondents receiving information about the purpose of the study and about the protection of GDPR data. In total, 2541 responses were collected. These raw data were examined and after eliminating the inconsistencies a sample of 2512 valid answers was obtained.

\subsection{Sample Description}

Table 2 includes the socio-demographic characteristics of the sample under analysis, consisting of 2512 citizens from Romania. Thus, out of the total respondents, $84.8 \%$ were females and $15.2 \%$ males. The explanation for the high participation of women in the survey compared to men is represented by the fact that, in Romania, women are traditionally the main responsible in the family for the acquisition and preparation of food [49]. The higher participation of women was also observed in other studies that aimed to evaluate the behavior of food consumption [49] or that related to food waste [36,37,39].

Most of the participants in the study were between 25-44 years old, with higher education and permanent residence in an urban area, county seat (big city). The high presence of this age segment can be justified by greater availability for participation in online surveys, increased interest in food-related topics, better Internet access in urban areas compared to rural areas [50], and higher frequency of use of social networks [51]. 
More than half of the respondents have a net monthly income between 826 and 3097 euros, falling into the socio-professional category of employee, and come from families composed of at least two people.

Table 2. Sample characteristics.

\begin{tabular}{|c|c|c|}
\hline Socio-Demographic Characteristics & Categories & Percentage \\
\hline \multirow{2}{*}{ Gender } & Male & $15.2 \%$ \\
\hline & Female & $84.8 \%$ \\
\hline \multirow{6}{*}{ Age } & $18-24$ & $14.8 \%$ \\
\hline & $25-34$ & $47.5 \%$ \\
\hline & $35-44$ & $26.4 \%$ \\
\hline & $45-54$ & $7.8 \%$ \\
\hline & $55-64$ & $2.8 \%$ \\
\hline & 65 years and over & $0.7 \%$ \\
\hline \multirow{6}{*}{ Education level } & Eighth grade & $0.3 \%$ \\
\hline & Vocational School & $0.7 \%$ \\
\hline & High School & $8.9 \%$ \\
\hline & Post-secondary school & $1.5 \%$ \\
\hline & Higher education (bachelor's degree) & $41.2 \%$ \\
\hline & Higher education (master's degree, doctorate) & $47.4 \%$ \\
\hline \multirow{8}{*}{ Socio-professional category } & Student & $10.6 \%$ \\
\hline & Unemployed & $1.4 \%$ \\
\hline & Household person & $5.1 \%$ \\
\hline & Employee & $64.6 \%$ \\
\hline & Freelancer & $7.2 \%$ \\
\hline & Business owner & $4.2 \%$ \\
\hline & Retired & $1.6 \%$ \\
\hline & Another occupation & $5.3 \%$ \\
\hline \multirow{5}{*}{ Monthly household income } & Under 825 EUR & $25.7 \%$ \\
\hline & Between 826 and 1650 EUR & $40.4 \%$ \\
\hline & Between 1651 and 3097 EUR & $20.3 \%$ \\
\hline & Over 3097 EUR & $5.9 \%$ \\
\hline & I do not know/I do not answer & $7.7 \%$ \\
\hline \multirow{3}{*}{ Permanent domicile } & In a rural, common/village area & $13.0 \%$ \\
\hline & In an urban area, small town & $10.9 \%$ \\
\hline & In an urban area, county seat & $76.1 \%$ \\
\hline \multirow{6}{*}{ Number of household members } & 1 person (live alone) & $13.7 \%$ \\
\hline & 2 persons & $39.6 \%$ \\
\hline & 3 persons & $24.3 \%$ \\
\hline & 4 persons & $17.1 \%$ \\
\hline & 5 persons & $4.0 \%$ \\
\hline & 6 persons and more & $1.3 \%$ \\
\hline
\end{tabular}

\subsection{Statistical Analysis}

In order to obtain representative clusters for the analyzed sample, we used the K-means clustering model, and to test whether the means are significantly different from each other, we used the Tukey's Honestly Significant Difference test. This model was also used by Richter [42] and Mallinson et al. [39] in identifying consumer clusters when they studied the issue of food waste in households. To create clusters, the first step was to standardize all variables and introduce them into the consumption profiling model. From here, using ANOVA, we determined whether any of the differences between the means are statistically significant by comparing the $p$-value to our significance level to assess the null hypothesis. The null hypothesis states that the population means are all equal. We chose the significance level of 0.05 which translates in a $5 \%$ risk of concluding that a difference exists when there 
is no actual difference. Based on this, the next step was to eliminate those variables that obtained a $p<0.05$ on the grounds that they do not contribute to the construction of clusters. After removing them, we started looking for a suitable number of clusters created. We achieved this by increasing and decreasing the number of clusters tested, until we reached as few iterations as possible in stabilizing the cluster centers, without unnecessarily increasing the total number of clusters. At the same time, we removed/re-added the variables that had the lowest $\mathrm{F}$ values until we managed to stabilize the model. We used the F-value this way because the F-distribution assumes that the null hypothesis is true and by placing the F-value from our study in the F-distribution we could determine how consistent our results are with the null hypothesis. This allows us to determine how common or rare our F-value is under the assumption that the null hypothesis is true. If the score was low, we concluded that our variable is inconsistent with the null hypothesis and it cannot help us in defining cluster membership.

\section{Results}

Following the analysis, three clusters of consumers were identified, according to socio-demographic factors, childhood habits, food waste habits, and general information on food waste, named "Careless", "Precautious" and "Ignorant." The K-means clustering model stabilized after 16 iterations. The iteration history (Table 3) shows the progress of the clustering process at each stage [52].

Table 3. Iteration history.

\begin{tabular}{cccc}
\hline Iteration & \multicolumn{3}{c}{ Change in Cluster Centers } \\
\hline & 1 & 2 & 3 \\
\hline 1 & 8.308 & 7.658 & 8.030 \\
2 & 1.839 & 0.269 & 1.100 \\
3 & 0.945 & 0.410 & 0.979 \\
4 & 0.441 & 0.471 & 0.808 \\
5 & 0.255 & 0.341 & 0.488 \\
6 & 0.189 & 0.232 & 0.305 \\
7 & 0.125 & 0.143 & 0.184 \\
8 & 0.084 & 0.091 & 0.109 \\
9 & 0.075 & 0.051 & 0.049 \\
10 & 0.076 & 0.040 & 0.041 \\
11 & 0.064 & 0.029 & 0.028 \\
12 & 0.056 & 0.018 & 0.034 \\
13 & 0.042 & 0.017 & 0.014 \\
14 & 0.023 & 0.009 & 0.011 \\
15 & 0.016 & 0.006 & 0.008 \\
16 & 0.000 & 0.000 & 0.000 \\
\hline
\end{tabular}

Convergence achieved due to no or small change in cluster centers. The maximum absolute coordinate change for any center is 0.000 . The current iteration is 16 . The minimum distance between initial centers is 14.296.

The ANOVA test indicated which of the variables contributes the best to the cluster solution, the variables with substantial $\mathrm{F}$ values providing the greatest separation between clusters [52].

Thus, in the construction of the model were retained those variables that are significant in terms of variation of the means and that have a substantial F-value to provide information of interest. The number of cases for each cluster was quite good (Table 4), with a ratio of 1.82 between the smallest and the largest cluster.

Table 4. Number of cases in each cluster.

\begin{tabular}{lrc}
\hline \multirow{2}{*}{ Cluster } & 1 & 522.000 \\
& 2 & 952.000 \\
& 3 & 905.000 \\
\hline \multicolumn{2}{c}{ Valid } & 2379.000 \\
Missing & 133.000 \\
\hline
\end{tabular}


The final cluster centers were calculated as the average for each variable within each cluster. Table 5 reflects the characteristics of each cluster.

Table 5. Final cluster centers.

\begin{tabular}{|c|c|c|c|}
\hline $\begin{array}{l}\text { Question } \\
\text { Number }\end{array}$ & $\begin{array}{l}\text { Cluster } 1 \\
\text { Careless }\end{array}$ & $\begin{array}{c}\text { Cluster } 2 \\
\text { Precautious }\end{array}$ & $\begin{array}{l}\text { Cluster } 3 \\
\text { Ignorant }\end{array}$ \\
\hline & $\begin{array}{l}\text { Standard } \\
\text { Deviation }\end{array}$ & $\begin{array}{l}\text { Standard } \\
\text { Deviation }\end{array}$ & $\begin{array}{l}\text { Standard } \\
\text { deviation }\end{array}$ \\
\hline \multicolumn{4}{|c|}{ Socio-demographic variables } \\
\hline Q1 & -0.13007 & 0.15528 & -0.08303 \\
\hline Q2 & -0.22928 & -0.01655 & 0.1029 \\
\hline Q3 & -0.07639 & -0.08614 & 0.13468 \\
\hline$\widehat{\mathrm{Q}} 4$ & -0.23828 & -0.06832 & 0.20131 \\
\hline Q5 & 0.21469 & 0.09859 & -0.21401 \\
\hline \multicolumn{4}{|c|}{ Childhood habits } \\
\hline Q6 & 0.30218 & 0.3159 & -0.51908 \\
\hline$\widehat{\mathrm{Q}} 7$ & 0.32349 & 0.41413 & -0.6232 \\
\hline Q8 & 0.23162 & 0.52893 & -0.71378 \\
\hline Q9 & 0.20412 & 0.46809 & -0.6215 \\
\hline Q10 & 0.27841 & 0.52989 & -0.73169 \\
\hline Q11 & -0.15206 & 0.26149 & -0.18261 \\
\hline Q12 & -0.00963 & 0.31168 & -0.33588 \\
\hline Q13 & -0.02534 & 0.26915 & -0.27059 \\
\hline Q14 & -0.08492 & 0.33307 & -0.31285 \\
\hline \multicolumn{4}{|c|}{ Food waste habits } \\
\hline Q15 & 0.10571 & -0.14029 & 0.09069 \\
\hline Q16 & -0.20251 & 0.33707 & -0.22568 \\
\hline Q17 & -0.10191 & 0.36611 & -0.31104 \\
\hline Q18 & -0.01054 & 0.38313 & -0.35993 \\
\hline Q19 & -0.05071 & 0.33846 & -0.28629 \\
\hline Q20 & -0.02418 & 0.37887 & -0.37208 \\
\hline$\hat{\mathrm{Q}} 21$ & -0.25713 & 0.34826 & -0.24366 \\
\hline Q22 & -0.12836 & 0.41215 & -0.33251 \\
\hline Q23 & -0.26201 & 0.27994 & -0.15203 \\
\hline Q24 & -0.2887 & 0.26517 & -0.11476 \\
\hline \multicolumn{4}{|c|}{ General information on food waste } \\
\hline Q25 & -0.2792 & 0.2848 & -0.13943 \\
\hline Q26 & -0.13678 & 0.18561 & -0.09013 \\
\hline$\widehat{\mathrm{Q}} 27$ & -0.17483 & 0.15943 & -0.08748 \\
\hline$\hat{\mathrm{Q}} 28$ & 0.15204 & -0.18614 & 0.12298 \\
\hline Q29 & -0.66279 & 0.25304 & 0.13787 \\
\hline Q30 & -0.9097 & 0.3785 & 0.14777 \\
\hline Q31 & -0.98658 & 0.38402 & 0.16174 \\
\hline Q32 & -0.63172 & 0.21986 & 0.16037 \\
\hline Q33 & -0.25272 & 0.17382 & -0.00314 \\
\hline Q34 & -0.80526 & 0.34284 & 0.0929 \\
\hline Q35 & -0.6859 & 0.31834 & 0.04921 \\
\hline Q36 & -0.76113 & 0.31161 & 0.09592 \\
\hline
\end{tabular}

Although there are statistically significant differences, the socio-demographic variables seem to provide the smallest variation in averages when it comes to building consumption archetypes. Thus, we can say that those who declare that they throw away food are not necessarily differentiated by these variables, the income being even more insignificant (Figure 1). 


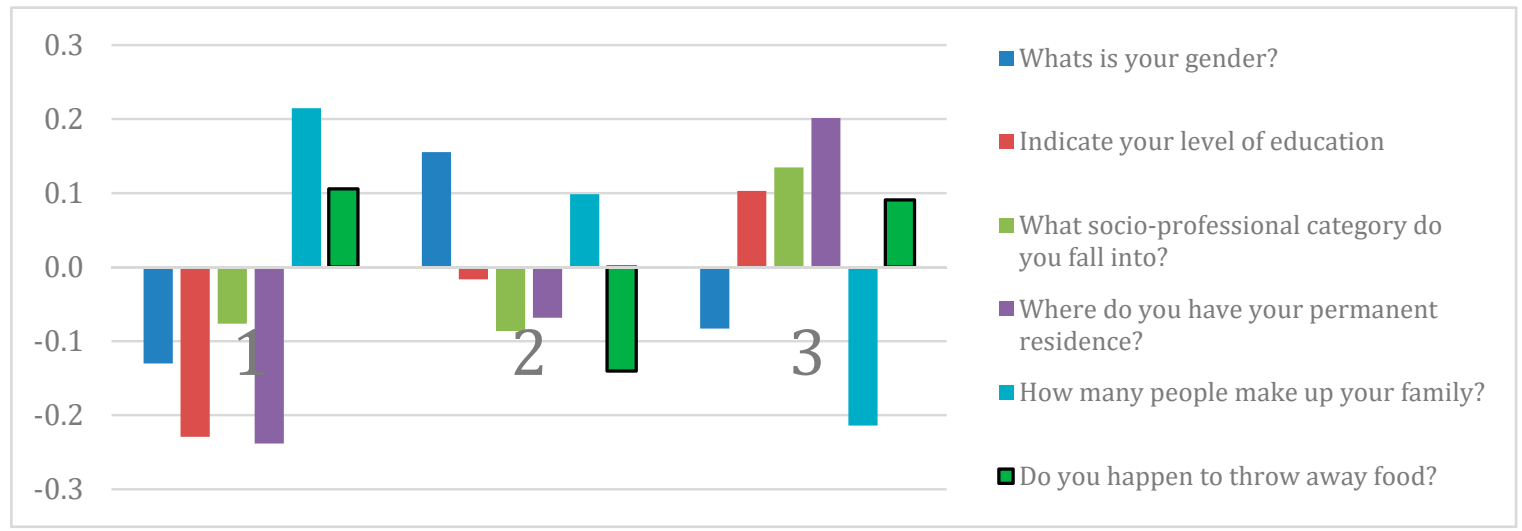

Figure 1. Clustering according to socio-demographic variables.

Cluster 1 "Careless" consists of those who throw food. They are generally women; they have a lower level of education and are employed. They come from rural or smaller cities and from families with more members.

Cluster 2 "Precautious" indicates those who do not throw away food. They are generally men, with an average education, employee status, living in small towns, and with medium-sized families.

Cluster 3 "Ignorant" also consists of those who throw away food. It is also dominated by women, with a high level of education, professionally active (both employees and freelancers/employers), residing in larger cities and coming from families with fewer people.

In terms of childhood habits, clusters 2 and 3 are the most polarized (Figure 2).

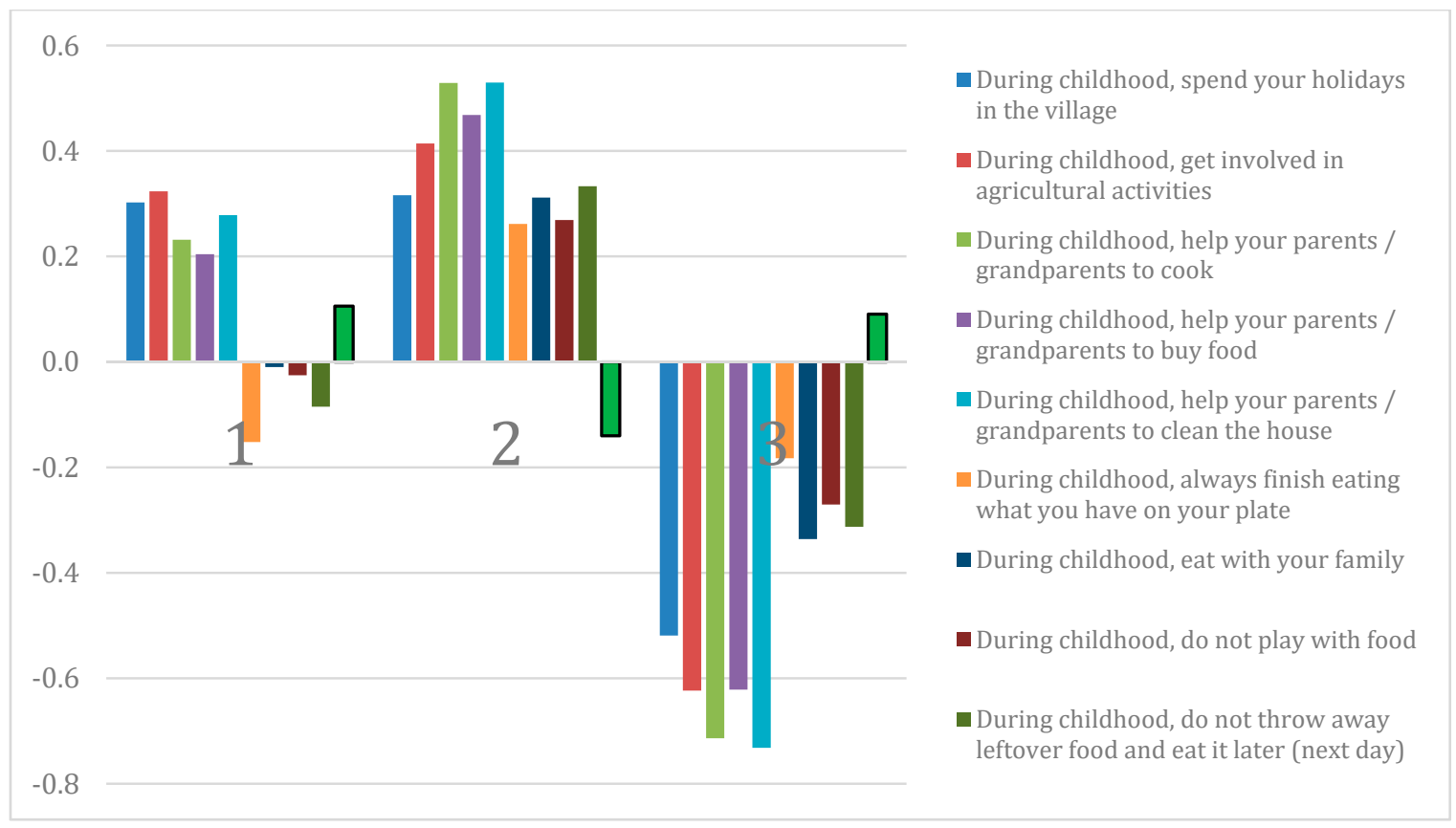

Figure 2. Clustering according to childhood habits.

Cluster 1 "Careless" includes those who had certain experiences during childhood, related to spending holidays in the country, involvement in agricultural activities, helping parents/grandparents to buy food and cooking. The parents generally did not ask them to finish the food on the plate or to eat with the family, nor to not play with the food or eat the leftovers later.

Cluster 2 "Precautious" includes those who went through all the childhood experiences mentioned above quite often, and parents often asked them to follow the rules of eating behavior. 
Cluster 3 "Ignorant" consists of people who, as children, had the opportunity very rarely or never to spend their holidays in the country or to engage in various household activities, and their parents did not ask them to follow certain rules or to dine with the family. The childhood habits of the respondents seem to have had an influence on the behaviors from adulthood regarding food waste. Thus, similarities can be seen quite easily between the previous graph, which illustrates clustering according to childhood habits (Figure 2) and the one illustrating clustering according to food waste habits (Figure 3).

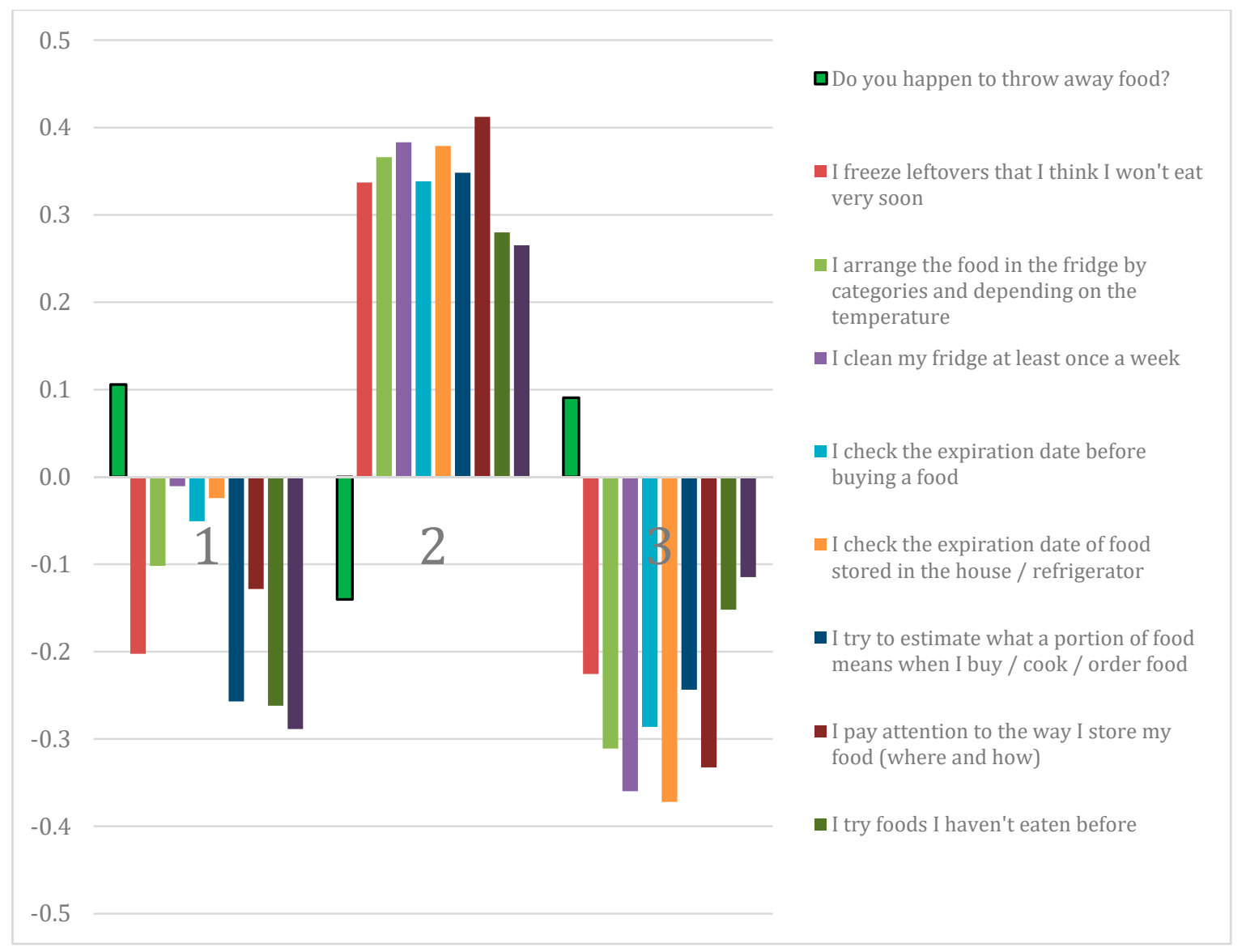

Figure 3. Clustering according to food waste habits.

Cluster 1 "Careless" is made up of people who generally have the following habits: they do not freeze food scraps, rarely arrange food in the refrigerator by temperature, clean the refrigerator less often, and not once a week, occasionally check the date validity of the food before buying it or the expiry date of those stored in the house/refrigerator. They do not estimate the quantities they need to cook, they do not pay attention to the way they store their food, they do not try new foods and they do not recycle the oil used for frying.

Cluster 2 "Precautious" is made up of people who say they take measures often enough or even always to limit food waste. The biggest difference between consumers in this cluster and those belonging to the other two identified clusters is given by the following habits: careful storage of food (where/how), checking their expiration date, and weekly cleaning of the refrigerator.

Cluster 3 "Ignorant" is represented by people who have not formed anti-waste habits, their actions taking place occasionally. They also do not freeze leftovers and do not estimate what a portion of food means when buying, cooking, or ordering food. Instead, they sometimes try new foods and recycle the oil used for frying. Otherwise, the other anti-waste habits are almost non-existent. 
Differentiation between clusters can also be made according to the general information of the respondents regarding food waste (Figure 4). If those in cluster 2 "Precautious" consider that everyone's food waste is to blame, those in cluster 1 "Careless" seem to think that no one is to blame for food waste and that this topic would not be of interest or even that it does not exist.

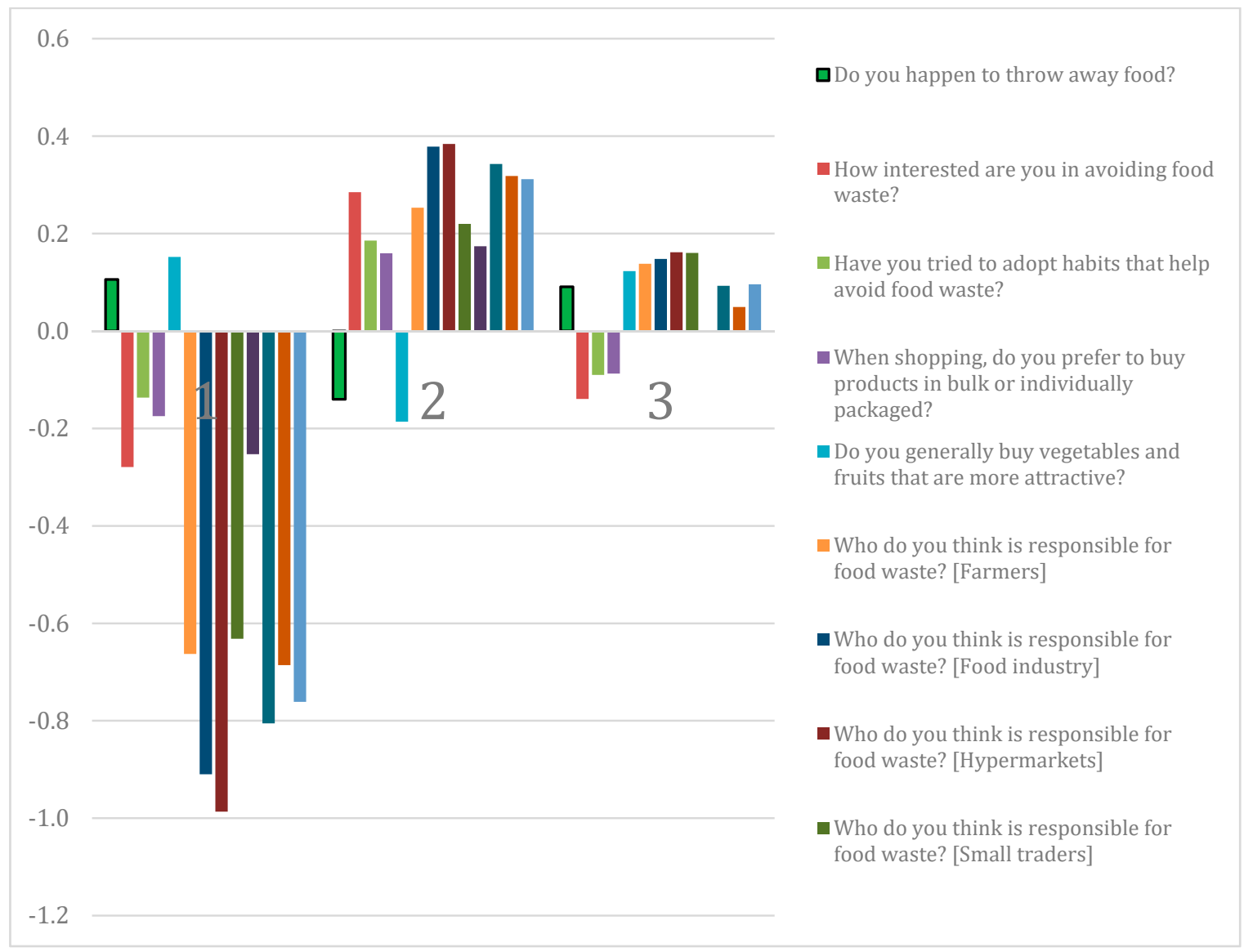

Figure 4. Clustering based on general food waste information.

Cluster 1 "Careless" is composed of people quite disinterested in the subject of food waste and who have not tried to adopt habits to reduce it. They prefer individually packaged products at the expense of bulk products. It could be somewhat agreed that food waste could be caused by consumers, but no one else in the agri-food chain is found guilty.

Cluster 2 "Precautious" is composed of people who say they are interested in the subject of food waste, adopt prevention habits, and choose bulk products more often. They believe that the culprits of food waste are those in the agri-food industry, hypermarkets, restaurants, canteens, and government institutions. Part of the blame also lies with farmers, small traders, and consumers.

Cluster 3 "Ignorant" includes self-proclaimed consumers slightly more interested in the problem of food waste, but who have rarely taken measures to combat this phenomenon. They prefer to some extent individually packaged foods and they consider that food waste is equally the fault of all actors involved in the agri-food chain, but less of their own fault, that of consumers.

Summarizing the elements that characterize each identified cluster, the people in cluster 1 "Careless" are those who throw away food, come from rural areas, and have a low level of education. They had some childhood experiences related to spending holidays in the country or engaging in domestic activities, but these did not lead to the formation of anti-waste habits. They do not have much information on the subject of food waste and do not seem to consider it "a problem." People belonging to the second "Precautious" cluster do not throw away food. They are generally a mixed group, in terms 
of socio-demographic characteristics. They had several experiences in childhood that materialized in adulthood in habits against food waste. They are well-informed and consider that all actors in the agri-food chain are to blame for the production of food waste and that each of them can contribute to reducing losses.

Those who belong to cluster 3 "Ignorant" throwaway food to the same extent as those in cluster 1. They are mostly from urban areas and have a high level of education. They had few childhood experiences related to spending holidays in the country, engaging in household activities, or following rules on family meals. They have not formed habits to prevent food waste. They have some information on this subject, and they consider guilty of food waste all those involved in the production and marketing of food, except consumers and themselves.

\section{Discussion}

The main purpose of the research was to evaluate the existence of consumer clusters in Romania based on their perception of food waste and the actual behavior related to this topic. The results revealed the existence of three clusters at the level of the investigated population: "Careless," "Precautious," and "Ignorant". Similar results were obtained in Italy by Talia et al. [38] who identified three clusters of consumers. Among them, the "Non-aware consumers" cluster in Italy has in common certain elements with the "Careless" in Romania: both clusters are made up of consumers from rural areas who do not feel responsible for food waste and do not have information about this topic. Another similarity resulting from the comparison of the clusters identified in the two countries is between "Conscious consumers" in Italy and "Precautious" in Romania: people belonging to these groups know the problem of food waste and try to avoid it as much as they can.

Romani et al. [40] identified not only extremes, namely consumers engaged in combating food waste, called "Virtuous," and consumers who throw away food, called "Waster," but also a category of consumers who have a moderate interest in this topic and who have the tendency to buy excessively, more than they need, thanks to the marketing tools of merchants. In Romania, we cannot say that we have identified a middle segment. Two consumer extremes "Uncaring food wasters" and "Caring" were also identified in Serbia [41]. Of the two clusters, we can say that "Uncaring food wasters" are quite similar to the "Careless" identified in this study in that they do not consider food waste a problem.

The indifference is so great that this category of consumers say that they often forget to eat the food they have. These results were also confirmed by Gaiani et al. [37] who identified a cluster entitled "The conscious-forgetful type." Checking the expiration date of food as a method of waste prevention is a feature of consumer behavior in the "Precautious" cluster. Similar results were obtained by Djekic et al. [41] in the study conducted in Serbia. Unlike the results of research conducted by Djekic et al. [41] and Richter [42] who identified as a significant variable in shaping clusters the presence of guilt among consumers, the present study could not confirm the importance of this variable.

The level of education does not always seem to be an important predictor of positive food waste behavior. Consumers in Romania belonging to the "Ignorant" group have a high level of education and come mainly from urban areas. This result is also confirmed by Delley and Brunner [43] who identified a similar consumer cluster in Switzerland, entitled "The indifferent," composed of people with a high level of education but disinterested in food waste. According to Gaiani et al. [37] a certain category of consumers belonging to the cluster "The conscious-fussy" waste food because it does not look good. This aspect is also confirmed by the results of the present study. Thus, consumers belonging to the "Careless" and "Ignorant" clusters prefer to buy and consume fruits and vegetables that are more "good-looking." 


\section{Conclusions}

Following the research, we were able to assess the behavior of households in Romania regarding food waste and to identify three distinct clusters of consumers, quite homogeneous within them, in terms of characteristics taken into account, but heterogeneous among themselves.

The result was three clusters that were labelled as follows: "Careless," "Precautious," and "Ignorant." Both the "Careless" and the "Ignorant" are the ones who throw away food. It seems that neither the environment of residence, nor the level of education or income had any influence on adopting anti-waste behaviors. Family education or childhood habits did not necessarily lead to the formation of correct habits of not wasting food.

Either the people who belong to the two clusters do not have much information about the concept of food waste, or they are ignorant people who do not care about this subject. They also do not consider food waste to be an issue in terms of economic, social, and environmental impact.

Another interesting aspect identified in those who waste food is the fact that they do not feel guilty in any way for this behavior, but rather make those who belong to other links in the agri-food chain responsible. Based on the results obtained, we believe that there would be a need for awareness raising and information campaigns at national level on the importance of combating food waste and the mechanisms that help reduce it.

Learning habits that lead to avoiding food waste (e.g., freezing food that is not eaten immediately, arranging food in the refrigerator by category and temperature, observing hygiene rules, checking the expiration date of food, storing it correctly and correct estimation of food portions) should be done in the family and at school. For this, it would be necessary to include in the school curricula some theoretical and practical subjects that would lead to the acquisition of knowledge and the formation of a sustainable behaviour.

The responsibility for initiating these campaigns lies with the public policy makers, but also with all the actors involved in the agri-food chain. The education and awareness campaigns carried out so far by the Ministry of Agriculture and Rural Development have materialized in the development of video materials (e.g., "How we can use food waste", "Correct freezing of food", "Smart shopping", "Correct storage of food", "Cooking stories"), educational games ("Everyday hero"), interactive tests and questionnaires ("Climate change in your kitchen", "The unknown part of food"). To these are added the numerous campaigns carried out by various non-governmental organizations, an example of which is the "Food Waste Combat" project.

Consumer awareness and information measures have had an effect on a certain category of people. These belong to the second cluster, which we called "Precautious". They are the ones who do not throw away food and who had certain childhood experiences that led to positive behaviors in adulthood. Thus, spending holidays in the country, engaging in agricultural activities, participating in the purchase and preparation of food with parents or grandparents or other household chores led them to appreciate food and be aware of its importance. Informing themselves, they managed to create certain mechanisms that help them to not waste food. The problem of food waste interests and empowers them, sometimes becoming activists themselves who fight for its solution. Education campaigns could also be used for consumers belonging to this cluster, to motivate them to continue to fight against food waste.

Our contributions to the progress of research in the field of food waste are of a scientific, methodological and practical nature. The clustering of Romanian consumers regarding the behaviour related to food waste is the first study of this kind, according to the authors. The results highlight the current situation in households on the issue of food waste and the need to continue awareness and education campaigns for those responsible for the purchase and preparation of food.

The results obtained can be translated into recommendations for public policy makers, for NGOs involved in the fight against food waste but also for the other actors involved: farmers, processors, distributors, and traders. Thus, both consumer awareness and global awareness can have a positive impact on reducing food waste and adopting sustainable production and consumption systems. 
Given the way of collection, we emphasize that a limitation of the research is exactly the promotion of the link to complete in profile groups, by a specialized NGO, which can attract more desirability in people's responses. In the following studies, we propose to the researchers to consider the introduction of control items in the verification of loyalty to the promotion page of the questionnaire and the comparison of the respondents' behaviors, depending on their environment of origin.

Author Contributions: The present paper has been conceived and designed by C.B.P. Conceptualization, C.B.P.; Introduction, C.B.P., M.P., A.-I.G. and A.B.-S.; Methodology, C.B.P., M.P. and A.A.; results and discussion, C.B.P., A.A. and A.-I.G.; statistical analysis and interpretation, A.A., C.B.P.; editing C.B.P., A.B.-S. and A.-I.G. All authors have read and agreed to the published version of the manuscript.

Funding: The study was conducted under a project entitled "Zéro Gaspillage - pour une production et une consommation responsables en ECO", 2019-2020, financed by "L'Agence Universitaire de la Francophonie en Europe Centrale et Orientale".

Conflicts of Interest: The authors declare no conflict of interest.

\section{References}

1. European Parliament. Report on How to Avoid Food Wastage: Strategies for a More Efficient Food Chain in the EU. 2011. Available online: https://www.europarl.europa.eu/doceo/document/A-7-2011-0430_EN.html (accessed on 11 November 2020).

2. Schanes, K.; Dobernig, K.; Gözet, B. Food waste matters-A systematic review of household food waste practices and their policy implications. J. Clean. Prod. 2018, 182, 978-991. [CrossRef]

3. Adamashvili, N.; Chiara, F.; Fiore, M. Food loss and waste, a global responsibility?! Econ. Agro-Aliment. 2019, 21, 825-846. [CrossRef]

4. The State of Food and Agriculture 2019. Moving Forward on Food Loss and Waste Reduction. CCBY-NC-SA 3.0 IGO. Rome: Licence. 2019. Available online: http://www.fao.org/3/ca6030en/ca6030en.pdf (accessed on 12 November 2020).

5. Van der Werf, P.; Gilliland, J.A. A systematic review of food losses and food waste generation in developed countries. In Proceedings of the Institution of Civil Engineers-Waste and Resource Management; Thomas Telford Ltd.: London, UK, 2017; Volume 170, pp. 66-77.

6. Principato, L. Food Waste at Consumer Level: A Comprehensive Literature Review; Springer: Cham, Switzerland, 2018; Available online: https://books.google.ro/books?hl=en\&lr=\&id=6qFTDwAAQBAJ\&oi=fnd\&pg=PP8\& $\mathrm{dq}=$ food + waste + worldwide+issue+ludovica\&ots=q3zh2X5F5B\&sig=zKGRp2xwj1r31SR3IXyEamj9CGs\& redir_esc $=\mathrm{y} \# \mathrm{v}=$ onepage $\& \mathrm{q}=$ foodwasteworldwideissueludovica $\& \mathrm{f}=$ false (accessed on 13 October 2020).

7. Bellemare, M.F.; Çakir, M.; Peterson, H.H.; Novak, L.; Rudi, J. On the Measurement of Food Waste. In American Journal of Agricultural Economics; Oxford University Press: Oxford, UK, 2017; Volume 99, pp. 1148-1158. [CrossRef]

8. Reutter, B.; Lant, P.; Reynolds, C.; Lane, J. Food waste consequences: Environmentally extended input-output as a framework for analysis. J. Clean. Prod. 2017, 153, 506-514. [CrossRef]

9. European Commission. Food Waste|Food Safety. Available online: https://ec.europa.eu/food/safety/food waste_en (accessed on 13 October 2020).

10. European Commission. Sustainable Development Goals. Available online: https://ec.europa.eu/info/strategy/ international-strategies/sustainable-development-goals_en (accessed on 13 October 2020).

11. Lombardi, M.; Costantino, M. A social innovation model for reducing food waste: The case study of an Italian non-profit organization. Adm. Sci. 2020, 10, 45. [CrossRef]

12. Stenmarck, Â.; Jensen, C.; Quested, T.; Moates, G.; Buksti, M.; Cseh, B.; Scherhaufer, S. Estimates of European Food Waste Levels; IVL Swedish Environmental Research Institute: Stockholm, Sweden, 2016. Available online: https://www.eu-fusions.org/phocadownload/Publications/ EstimatesofEuropeanfoodwastelevels.pdf (accessed on 13 October 2020).

13. BIOREGIO|Interreg Europe. Available online: https://www.interregeurope.eu/bioregio/ (accessed on 15 October 2020).

14. Reducing Food Waste-Method for Measuring Waste Quantities. Available online: https://ec.europa.eu/info/ law/better-regulation/have-your-say/initiatives/2122-Establishment-of-a-methodology-of-measurementof-food-waste (accessed on 13 November 2020). 
15. Katajajuuri, J.-M.; Silvennoinen, K.; Hartikainen, H.; Heikkilä, L.; Reinikainen, A. Food waste in the Finnish food chain. J. Clean. Prod. 2014, 73, 322-329. [CrossRef]

16. Silvennoinen, K.; Katajajuuri, J.M.; Hartikainen, H.; Heikkilä, L.; Reinikainen, A. Food waste volume and composition in Finnish households. Br. Food J. 2014, 116, 1058-1068. [CrossRef]

17. Herzberg, R.; Schmidt, T.G.; Schneider, F. Characteristics and determinants of domestic food waste: A representative diary study across Germany. Sustainability 2020, 12, 4702. [CrossRef]

18. Giordano, C.; Alboni, F.; Falasconi, L. Quantities, determinants, and awareness of households' food waste in Italy: A comparison between diary and questionnaires quantities. Sustainability 2019, 11, 3381. [CrossRef]

19. Eriksson, M.; Giovannini, S.; Ghosh, R.K. Is there a need for greater integration and shift in policy to tackle food waste? Insights from a review of European Union legislations. SN Appl. Sci. 2020, 2, 1-13. [CrossRef]

20. Andreea, A.L.; Laurentiu, P.I.; Maria, N.I.C.A.; Silviu, I.A. Food waste analysis in Romania in comparison to the European Union. Ann. Fac. Econ. 2019, 1, 227-239.

21. Anul 2014. Anul Combaterii Risipei Alimentare. Available online: https://www.madr.ro/docs/ind-alimentara/ risipa_alimentara/anul-2014-anul-combaterii-risipei-alimentare.pdf (accessed on 14 October 2020).

22. LEGE Nr. 217 Din 17 Noiembrie 2016 Privind Diminuarea Risipei Alimentare-REPUBLICARE*). Available online: http://legislatie.just.ro/Public/DetaliiDocument/183792 (accessed on 14 October 2020).

23. Gheorghescu, I.C.; Balan, I.M. Managing, minimizing and preventing food waste from Romania in the European context. Lucrări Stiintifice Management Agricol. 2019, 21, 58.

24. Cantaragiu, R.E. Corporate social entrepreneurship initiatives against food waste-The case of Lidl in Romania. Proc. Int. Conf. Bus. Excel. 2019, 13, 505-514. [CrossRef]

25. Dumitru, I.; Burghiu, A.G. Romanian food waste analysis. In New Trends in Sustainable Business and Consumption; Editura ASE: Bucharest, România, 2019; p. 441.

26. Ionita, I. Click to Feed. Mobile phone applications' role in improving food access in Romania. Interações 2018, 34, 161-187. [CrossRef]

27. Ghinea, C.; Ghiuta, O.-A. Household food waste generation: Young consumers behaviour, habits and attitudes. Int. J. Environ. Sci. Technol. 2018, 16, 2185-2200. [CrossRef]

28. Stefan, V.; Van Herpen, E.; Tudoran, A.A.; Lähteenmäki, L. Avoiding food waste by Romanian consumers: The importance of planning and shopping routines. Food Qual. Prefer. 2013, 28, 375-381. [CrossRef]

29. Iorga, S.C.; Apostol, L.; Belc, N.; Moșoiu, C.E.; Berca, L.M.; Niculae, O.M.; Popa, M.E. Profile of high risk wasting food consumer in Romania. Sci. Bull. Ser. F. Biotechnol. 2017, 21, 301-307.

30. Cantaragiu, R.E. The impact of gender on food waste at the consumer level. Stud. Univ. Vasile Goldis Arad Econ. Ser. 2019, 29, 41-57. [CrossRef]

31. Cantaragiu, R.; Hadad, S.; Condrea, E. Food waste and rural tourism-A Romanian perspective. Ovidius Univ. Ann. Econ. Sci. Ser. 2019, 19, 152-160.

32. Okumus, B.; Taheri, B.; Giritlioglu, I.; Gannon, M.J. Tackling food waste in all-inclusive resort hotels. Int. J. Hosp. Manag. 2020, 88, 102543. [CrossRef]

33. Caprita, D.E. Reducing Food Waste in order to Become the Zero Hunger Generation. Competitiveness of Agro-Food and Environmental Economy. 2016; pp. 189-203. Available online: https://search.proquest.com/ docview/1938846478?pq-origsite=gscholar\&fromopenview =true (accessed on 17 October 2020).

34. Petrescu-Mag, R.M.; Petrescu, D.C.; Burny, P. Resilience to environmental pressure through quality food demand: Meat consumption in Romania. Environ. Eng. Manag. J. 2017, 16, 2391-2400. [CrossRef]

35. Chivu, R.G.; Stoica, I.; Orzan, G.; Radu, A.-V. Discounts or happy money for efficient inventory management? A new trend on Romanian markets in changing the consumer behaviour. New Trends Issues Proc. Humanit. Soc. Sci. 2018, 5, 82-88. [CrossRef]

36. Falasconi, L.; Cicatello, C.; Franco, S.; Segre, A.; Setti, M.; Vttuari, M.; Cusano, I. Consumer approach to food waste: Evidences from a large scale survey in Italy. Italian Rev. Agric. Econ. 2016, 71, 266-278.

37. Gaiani, S.; Caldeira, S.; Adorno, V.; Segrè, A.; Vittuari, M. Food wasters: Profiling consumers' attitude to waste food in Italy. Waste Manag. 2018, 72, 17-24. [CrossRef]

38. Di Talia, E.; Simeone, M.; Scarpato, D. Consumer behaviour types in household food waste. J. Clean. Prod. 2019, 214, 166-172. [CrossRef]

39. Mallinson, L.J.; Russell, J.M.; Barker, M.E. Attitudes and behaviour towards convenience food and food waste in the United Kingdom. Appetite 2016, 103, 17-28. [CrossRef] 
40. Romani, S.; Grappi, S.; Bagozzi, R.P.; Barone, A.M. Domestic food practices: A study of food management behaviors and the role of food preparation planning in reducing waste. Appetite 2018, 121, 215-227. [CrossRef] [PubMed]

41. Djekic, I.; Miloradovic, Z.; Djekic, S.; Tomasevic, I. Household food waste in Serbia-Attitudes, quantities and global warming potential. J. Clean. Prod. 2019, 229, 44-52. [CrossRef]

42. Richter, B. Knowledge and perception of food waste among German consumers. J. Clean. Prod. 2017, 166, 641-648. [CrossRef]

43. Delley, M.; Brunner, T.A. Foodwaste within Swiss households: A segmentation of the population and suggestions for preventive measures. Resour. Conserv. Recycl. 2017, 122, 172-184. [CrossRef]

44. Elimelech, E.; Ert, E.; Ayalon, O. Bridging the gap between self-assessments and measured household food waste: A hybrid valuation approach. Waste Manag. 2019, 95, 259-270. [CrossRef]

45. Giordano, C.; Piras, S.; Boschini, M.; Falasconi, L. Are questionnaires a reliable method to measure food waste? A pilot study on Italian households. Br. Food J. 2018, 120, 2885-2897. [CrossRef]

46. Van Der Werf, P.; Seabrook, J.A.; Gilliland, J.A. Food for thought: Comparing self-reported versus curbside measurements of household food wasting behavior and the predictive capacity of behavioral determinants. Waste Manag. 2020, 101, 18-27. [CrossRef]

47. Cicatiello, C. Measuring household food waste at national level: A systematic review on methods and results. CAB Rev. 2018, 13, 1-8. [CrossRef]

48. Le Borgne, G. Sensibilité du Consommateur au Gaspillage Alimentaire: Conceptualisation, Antécédents, et Conséquences. Ph.D. Thesis, University of Montpellier, Montpellier, France, 2015. Available online: https://www.researchgate.net/publication/316535630_Sensibilite_du_consommateur_au_ gaspillage_alimentaire_conceptualisation_antecedents_et_consequences (accessed on 15 October 2020).

49. Voinea, L.; Popescu, D.V.; Bucur, M.; Negrea, T.M.; Dina, R.; Enache, C. Reshaping the traditional pattern of food consumption in Romania through the integration of sustainable diet principles. A qualitative study. Sustainability 2020, 12, 5826. [CrossRef]

50. Rusu, V.; Neculiță, R.C.; Cristea, M.; Mogodan, A.; Petrea, Ș.; Simionov, I. Sustainable development of rural areas of South-East Region of Romania. Sci. Papers Manag. Econ. Eng. Agric. Rural Dev. 2020, 20, 523-529.

51. Dabija, D.C.; Babut, R.; Dinu, V.; Lugojan, M.I. Cross-Generational Analysis of Information Searching Based on Social Media in Romania. Transformations in Business \& Economics. 2017; p. 16. Available online: http://eds.a.ebscohost.com/abstract?site=eds\&scope=site\&jrnl=16484460\&asa=Y\&AN=123251669\&h= tiiaq0F5PMv0fvRrFyk3el8\%2BeLVr51gYlBlEIZFZ9WhtPvsgLBF604n5idBucjO3zbvp3bikBAeYXfeRZyJjtg\% 3D\%3D\&crl=c\&resultLocal=ErrCrlNoResults\&resultNs=Ehost\&crlhashurl=login.aspx\%3Fdirect \% 3Dtrue\%26profile\%3Dehost\%26scope\%3Dsite\%26authtype\%3Dcrawler\%26jrnl\%3D16484460\%26asa\% 3DY\%26AN\%3D123251669 (accessed on 24 October 2020).

52. Using K-Means to Classify Customers. Available online: https://www.ibm.com/support/knowledgecenter/ en/SSLVMB_24.0.0/spss/tutorials/kmeans_telco_intro.html (accessed on 24 October 2020).

Publisher's Note: MDPI stays neutral with regard to jurisdictional claims in published maps and institutional affiliations.

(C) 2020 by the authors. Licensee MDPI, Basel, Switzerland. This article is an open access article distributed under the terms and conditions of the Creative Commons Attribution (CC BY) license (http://creativecommons.org/licenses/by/4.0/). 